\title{
Academic self-control scale for secondary school students: Validity and reliability study
}

\author{
Hanife Büyük \\ Ministry of National Education, Ankara, Turkey, hanifeyasav@gmail.com \\ Selahiddin Öğülmüş \\ Ankara University, Ankara, Turkey, s.ogulmus@gmail.com \\ Emine Gül Kapçı \\ Ankara University, Ankara, Turkey, eminegulkapci@gmail.com
}

Check for updates

\begin{abstract}
Academic self-control refers to the individual's self-control behaviors in the academic field. The study reported in this article aims to develop a valid and reliable instrument for evaluating the academic selfcontrol behaviors of secondary school students between the ages of 11-14. The study sample consists of 1087 students (female $\mathrm{n}=545$; male $\mathrm{n}=539$; unreported $\mathrm{n}=3$ ) in Ankara, Turkey. As a result of the Principal Component Analysis (PCA) conducted to evaluate the construct validity of the Academic SelfControl Scale (ASCS), two factors named "academic perseverance" and "academic attention" were determined. These factors explained $47.11 \%$ of the variance in the participants' academic self-control scores. Additionally, Confirmatory Factor Analysis (CFA) results confirmed the suitability of the factor structure. The Academic Perseverance Scale was used for criterion validity, and a positive correlation (.74) was found. The internal consistency reliability measured using Cronbach Alpha was found .81 . The testretest reliability result was .93 . These findings indicate that the ASCS could be used to assess academic selfcontrol of secondary school students.
\end{abstract}

Keywords: Academic self-control, Adolescence, Scale development, Self-control.

\section{Ortaokul öğrencilerinde akademik öz denetim ölçeğinin geliştirilmesi: Geçerlik ve güvenirlik çalışması}

ÖZ Akademik öz denetim, bireyin akademik alanla ilişkili öz denetim davranışlarını ifade etmektedir. Bu çalışmada 11-14 yaş aralığındaki ortaokul öğrencilerinin akademik alanda gösterdikleri öz denetim davranışlarını değerlendiren geçerli ve güvenilir bir ölçme aracı geliştirmek amaçlanmıştır. Çalışma grubunu Ankara İli'nde toplam üç ortaokulda öğrenim gören 1087 öğrenci $(k 1 z ~ n=545$; erkek n = 539; cinsiyetini belirtmeyen $n=3$ ) oluşturmaktadır. Akademik Öz Denetim Ölçeği'nin (AÖDÖ) yapı geçerliğini test etmek üzere yapılmış olan Temel Bileşenler Analizi (TBA) sonucunda "akademik sebat" ve "akademik dikkat" olarak adlandırılan iki faktör belirlenmiștir. Bu faktörler varyansın \%47.11'ini açıklamıștır. Ayrıca, Doğrulayıcı Faktör Analizi (DFA) sonuçları faktör yapısının uygunluğunu desteklemiştir. Ölçüt geçerliği için kullanılan Akademik Azim Ölçeği ile AÖDÖ arasındaki korelasyon .74 olarak bulunmuştur. Cronbach Alfa ile değerlendirilen iç tutarlık güvenirliği .81 ve dört hafta ara sonucunda elde edilen test tekrar test güvenirliği .93 olarak hesaplanmıştır. Bu sonuçlar AÖDÖ’nin ortaokul öğrencilerinde akademik öz denetimin ölçülmesine yönelik uygulama ve araştırmalarda kullanım değerinin olduğuna işaret etmektedir.

Anahtar

Akademik öz denetim, Ergenlik, Ölçek geliştirme, öz denetim

Citation:

Büyük, H., Ögülmüş, S., \& Kapçı, E.G., (2020). Academic self-control scale for secondary school students: Validity and reliability study. Turkish Journal of Education, 9(4), 290-306. DOI:

10.19128/turje. 778117 


\section{INTRODUCTION}

Self-control refers to an effortful control over tendencies and desires (Duckworth \& Seligman, 2017). It can be defined as the regulation of actions, thoughts, and emotions to delay gratification. When current valuable goals conflict with more desired ones (Duckworth, Taxer, Eskreis-Winkler, Galla, \& Gross, 2019), contradictions may occur between the current situation and the gratifying ones. This self-initiated ability allows the individual to be motivated to change his/her behavior, and so the conflicts experienced may be resolved (Baumeister \& Vohs, 2007).

Self-control exerts influence on different areas of life, such as health, academia, addictions, and workrelated or psychological well-being. Instead of experiencing the short-term pleasure of the current desired action (e.g., the pleasure of surfing on social media), delaying that pleasure (leaving the phone for another day) and being aware of the long-term gain (obtaining a good score from the exam) enable the individual to be more successful (Cho, Kim, \& Kim, 2018). Self-control shown particularly in the academic field is known as academic self-control. Kenneth (1994) defined academic self-control behaviors as academic resourcefulness and described these behaviors as action-oriented. He claimed that they include perseverance, self-study, delaying instant gratification, using time effectively, planning, and problem-solving strategies. They also entail using effective coping strategies, such as positive self-statements to manage stress and struggle against academic difficulties (Kennett \& Keefer, 2006). Self-control is one of the most effective driving forces that enables the student to engage in distance education and continue learning within the existing possibilities instead of displaying any other pleasurable behaviors, such as interacting with friends on social media or watching a favorite program. It has grown in importance to take the responsibility of academic development, especially with the interruption of formal education due to the COVID-19 pandemic. Millions of students have faced the challenge of maintaining their education distantly outside of their school, and therefore academic selfcontrol is required more than ever (UNESCO, 2020). Without an authority figure or a fear of underachievement, students who willingly attend the online courses and fulfill their academic requirements are the ones who have higher academic self-control (Kenneth \& Reed, 2009). Nowadays, given that the Internet is a major distractor for children and adolescents, it is not an easy endeavor to show self-control for long-term goals by resisting the temptations. According to Tangney, Baumeister and Boone (2004), individuals with high academic self-control obtain better grades in the long term, prevent leisure activities from hindering lessons, use their working time more effectively, are better at choosing appropriate courses and activities, and can keep emotional distractions from impairing their performance. It is known that these individuals are those who set goals for themselves, think positively in the face of difficulties and expectations, take notes, and arrange their environment to facilitate learning, apply for self-assessments, and review written materials. If these individuals obtain low scores in a test or an assignment, they redefine their academic goals and strategies by evaluating the possible causes of failure (Kennett \& Keefer, 2006). The literature suggests that students who listen more carefully to the course, who can suppress the desire to speak with their friends during the course, who are more rigorous about doing homework and preparing for the exams, who are organized and goaloriented, receive higher grades than their peers (Duckworth et al, 2019; Martin, Kennett, \& Hopewell, 2019; Nebioğlu, Konuk, Akbaba, \& Eroğlu, 2012; Tangney et al, 2004). In short, students with high academic self-control neither give up easily nor become worried. Instead, these individuals look for ways to solve problems and use effective methods to succeed. Studies conducted with university students (Duckworth et al, 2019; Kennett \& Keefer, 2006) have revealed that not only are these students involved in university's social and academic environment but also, that their justification for attending university depends on more intrinsic reasons (such as enjoying learning). These students are also individuals who postpone their academic responsibilities less and are less likely to please others as they aim at attending university (Kennett, Reed, \& Stuart, 2013). 
In the theoretical framework of self-control, it is seen that a wide range of theories have been discussed. Among these theories are the General Crime Theory proposed by Gottfredson and Hirschi (1990), which claims that self-control is the most important factor preventing the person from committing a crime, and that this can be increased by early interactions; and the Self-Determination Theory (Ryan \& Deci, 2000), which explains self-control through motivational sources and argues that self-control is an intrinsic regulation. Another theory to enlighten self-control, the Strength Model (Baumeister, 2002) claims that with the help of exercises, self-control can be increased, thereby it emphasizes the similarity between self-control and muscles. The Attribution Theory is also one of the theories addressed to seek an explanation for self-control. According to this theory, the factors with which individuals explain the causes of their success/failure -talent, effort, the difficulty of duty, luck- can shed light onto the emergence of self-control behavior. For example, when facing an academic challenge, the student's belief in herself/himself that if she/he struggles enough, she/he can succeed in, prompts her/him to perform self-control. Another theoretical explanation is provided by the Theory of Self-Efficacy (Bandura, 1977) positing that individuals' belief in their abilities to manage forward-looking situations mobilizes the individuals, and thus increases the likelihood of the realization of action. Similarly, according to Gross and Thompson's (2007) Process Model of Self-Control, impulses may decrease or increase in a situation, attention, appraisal and response cycle. Therefore, the situation that the student chooses to be in influences where she/he directs her/his attention; in turn, where she/he directs her/his attention influences how she/he appraises her/his situation; and this appraisal then helps them determine how to respond. All these processes are dependent on how information is processed, and so they are somehow related with age. As the capacity of self-control is age-related, self-control is naturally identified as metacognitive because higher-order mental processes are needed (Duckworth, Gendler, \& Gross, 2014). In a study, Mischel (1981) found that older children (aged 12) show more self-control thanks to their better sophisticated thinking and metacognitive skills. Definitely, growing older is not enough alone, but also, social interactions and support of caring adults are essential during school age for self-control.

In the Academic Self-Control Model proposed by Martin and Kennett (2018), two dimensions are discussed; namely, academic self-compassion and academic resourcefulness. Self-compassion, which can be described as a gentle and compassionate approach to personal failures, has been discussed as a predictor variable in academic self-control studies in recent years (Martin \& Kennett, 2018; Martin et al, 2019). Previously, Rosenbaum (1980) adopted the concept of "learned resourcefulness" to explain why some students cope with academic challenges more easily or enjoy academic challenges and better adapt to the academic environment. Later, according to the model proposed by Rosenbaum (1990), having resources to cope with difficulties and obstacles faced by individuals in achieving their academic goal contributes to generalizing academic context and displaying academic self-control behavior. In consideration of all these explanations, the components of academic self-control can be summarized as academic resourcefulness (Martin \& Kenneth, 2018), general resourcefulness (Rosenbaum, 1980), academic self-efficacy, and attributions to failure (Rosenbaum 1990, 2000).

Considering the developmental process of self-control, the secondary school period is of critical importance (Oriol, Miranda, Oyanedel, \& Torres, 2017). In Turkey, around age six, children begin primary education and this includes four grades while secondary school refers to grade five through eight (9-14 aged). The transition from primary or elementary school to secondary school mostly coincides with puberty and puberty is an important factor promotes naturalistic improvements in selfcontrol. However, some studies showed that within the period of puberty intrinsic motivation declines as age increases (Casey \& Caudle, 2013; Duckworth et al, 2014). On the other hand, adolescents are capable of regulating their behaviors, thoughts and emotions with the maturation of prefrontal cortex so learning to delay gratification and avoiding external distractors become more probable after the onset of adolescence (Oriol et al, 2017). According to brain-based studies (Blakemore, den Ouden, Choudhury, \& Frith, 2007), the limbic system, which is the reward center of the brain, directs adolescents to the quest for pleasure and begins to develop rapidly during this period (Steinberg, 2008). With intensified emotions, adolescents become more open to possible risks. However, the development rate of the prefrontal cortex responsible for high-level thinking skills during the same period is not so high. Since self-control skills are not fully developed yet, the adolescent is more likely to be exposed to risks. The 
secondary school period is a risky period during which the child becomes more familiar with antisocial behavior and substance use, and peer influence can result in permanent problems. Supporting selfcontrol skills of an early adolescent may prevent possible negative outcomes of their adolescence.

Gottfredson and Hirschi (1990) claim that ineffective parenting with low discipline, intimacy and monitoring increases the probability of low self-control. The authors maintain that "absence of nurturance, discipline, or training" gradually fosters low self-control (p. 95). Studies show that selfcontrol continues to develop throughout adolescence due to the adolescent's neuroflexibility, and that the parent's role in this development process is significant (Casey \& Caudle, 2013; Cauffman, Steinberg, \& Piquero, 2005). Other factors, such as negative environment (e.g., a high crime rate) and low socioeconomic levels, are among other risk factors (Bridgett, Burt, Edwards, \& Deater-Deckard, 2015). Another important factor in academic self-control in students is schools. The ways in which educators manage the classroom and perform education, such as explaining a difficult subject, directly affect the behavior of the student (Arnesen, Elstad, \& Christophersen, 2017; Mortimore, 1993).

The literature shows that self-control behaviors in the academic field are mostly measured using general self-control scales, in a cognitive manner. Furthermore, there are some original and adaptive instruments that can be associated with the concept of academic self-control which measure academic resilience (Kapıkıran, 2012; Martin \& Marsh, 2006), academic determination (Bozgün \& Başgül, 2018), academic self-efficacy (Öncü, 2012), academic self-regulation (Durmaz, 2012; Ryan \& Connell, 1989) or academic locus of control (Sarı̧am, 2014).

The Academic Resourcefulness Inventory, developed by Kennett (1994), is one of the instruments used to measure academic self-control in university students. It assesses the use of students' self-statements to struggle with the academic demands such as, for example, the student's ability to delay instant gratification in order to carry out an academic duty (e.g., "I am successful/not successful on homework delivery dates").

Based on the literature review presented above, the study reported in this article set out to develop a reliable and valid instrument that can be used to measure academic self-control skills of secondary school students between the ages of 11 and 14. Self-control lies at the heart of learners' efforts to achieve successful academic performance (Arnesen et al, 2017). In Turkey, the development of academic selfcontrol in the secondary school process is regarded as important in terms of both career and development. It is developmentally important because in the transition from childhood to adolescence, it is likely to protect the adolescent from risks. On the other hand, in terms of career, choice of high school mostly determines one's future career in Turkey. However, as the literature shows, there is no available instrument to measure academic self-control of secondary school students.

Measuring academic self-control may contribute to the development and effectiveness of individual or group intervention programs for the development of this skill and to increase academic success in the long term. Strengthening academic self-control may have positive outcomes not only for the student, but also for all learning that takes place in the educational process. Importantly, "self-control" is accepted as one of the ten root values in the renewed teaching programs of the Ministry of National Education in Turkey, and developing self-control in children is among the primary goals (MoNE; 2017). Therefore, a valid and reliable instrument is needed to measure the self-control skills that secondary school students use while meeting the expectations and demands of academic life.

\section{METHODOLOGY}

The present study uses a descriptive method of research. Descriptive studies aim at depicting the current situation (Karasar, 2004). The following section includes information on the study group of this research, the scale development process, data collection, and analysis of the data. 


\section{Participants}

Data for the current study were collected from different study groups and analyzed at different stages of the scale development process. The study sample was comprised of a total of 1,087 students, including $545(50.14 \%)$ female and $539(49.59 \%)$ male, and three students $(0.27 \%)$ who didn't report their genders. The students attended from three different public secondary schools in Ankara, Turkey during the 2019-2020 academic year and they were labelled under four groups to cater for the scale development process.

In the first study group, there were 3505 th -8 th graders, including $178(50.86 \%)$ female and 172 $(49.14 \%)$ male. The average age of this group was 11.46 , and the standard deviation was 1.10 . In the second study group, a total of 230 5th -8 th graders, $118(51.30 \%)$ female and $112(48.70 \%)$ male participated. The average age of this group was 11.98, and the standard deviation was 1.04. The third study group is the one from which data were collected to conduct Principal Component Analysis (PCA) for the scale. This group consisted of $2106 \mathrm{th}-8$ th grade students, including 111 male $(52.86 \%)$ and 99 female students $(47.14 \%)$. The average age of this group was 12.14 , and the standard deviation was 0.96. The fourth study group is the one from which data were collected to conduct Confirmatory Factor Analysis (CFA) for the scale. This group consisted of 297 6th - 8th graders, including 150 (51\%) female and $144(49 \%)$ male. The average age of this group was 12.92, and the standard deviation was 0.97 .

\section{Process}

The scale development phases proposed by DeVellis (2017) were followed in the Academic SelfControl Scale (ASCS) development process. Therefore, the scale development process began with determining the phenomena clearly. Generating an item pool, having item pool reviewed, administering items to pilot sample, evaluating items and producing final scale are the next steps. To explain the theoretical structure of the concept, journals and books published in Turkey and abroad in the fields of education and psychology were scanned in scientific indexes using related keywords (e.g., academic self-control, academic self-regulation, etc.), and similar measurement tools were examined. For clarifying the phenomenon being studied, individual and group interviews with secondary school teachers and students were also conducted. These interviews were used to explain self-control skills that secondary school students have in the academic context, in addition to support from the literature.

Reviewing the relevant studies in the literature, self-awareness, attention focus, overriding one's inner responses, interrupting undesired tendencies/impulses, delaying gratification, resisting temptations, not giving up despite ongoing challenges (perseverance, grit), using problem-solving strategies, being planned and responsible, using time effectively, setting goals for the future, struggling with difficulty and constraint under stress, and positive self-statements (self-compassion) were included within the concepts of academic self-control. These skills were categorized under two dimensions in the scale: academic attention and academic perseverance. At the end of both the literature review and interviews and observations with secondary school teachers and students, these two dimensions were discussed in three contexts: class environment, homework, and examinations. By determining the components of the dimensions related to contexts, behavioral indicators were determined and presented in Table 1.

Table 1.

Dimension-context-component table for the academic self-control variable

\begin{tabular}{clc}
\hline \multicolumn{1}{c}{ Dimensions } & \multicolumn{1}{c}{ Academic Self Control } & \multicolumn{1}{c}{ Components } \\
\hline \multirow{4}{*}{ Academic attention } & Self-awareness & \\
& Attention focus & \\
& Resisting temptations/inhibition & Class environment \\
& Delaying gratification & Exams \\
& Being planned & Assignments \\
Academic perseverance & Perseverance & \\
& Evaluating alternatives & \\
& Sticking to academic goals & \\
\hline
\end{tabular}


In the creation of the item pool, items which may be indicative of the components given in Table 1 were taken into account and 96 items were written at the beginning. The number of items was reduced to 54 items by removing some and combining the similar ones according to the expert opinion. A trial form consisting of 54 items was applied to the first study group $(N=350)$. After the preliminary study, the item-total correlations and factor structure of the scale were examined. Since item-total correlations are recommended to be between .30 and .70 (Büyüköztürk, 2010), the number of items was reduced to 29 due to cross or low factor loadings. This new 29-item version of the scale was subjected to expert opinion. The experts (two experts in the field of measurement and assessment, two experts in the educational psychology field, two experts in the psychological counseling and guidance field and one Turkish language expert) were asked to evaluate each item in terms of content validity, whether the dimensions and behavioral indicators were related to academic self-control, language clarity, applicability of the form and suitability for the target group's age level. These assessors were asked to provide feedback under the following headings: (1) Appropriate, (2) Not Appropriate and (3) Suggestion (Partially Appropriate). After the expert evaluations, a form with 21 items was obtained for the scale after removal of some items and changes of some statements (Table 2).

Table 2.

Changed or removed items of the ASCS after expert opinion

\begin{tabular}{|c|c|}
\hline The old version & The new version/Suggestion \\
\hline I go to school with my homework done. & I forget to do my homework. \\
\hline My teachers and friends say I disrupt the class. & My teachers warn me that I disrupt the class. \\
\hline $\begin{array}{l}\text { It takes me a long time to bring my attention back } \\
\text { when I am distracted during class. }\end{array}$ & Removed \\
\hline $\begin{array}{l}\text { I think the education I receive is important for my } \\
\text { future life. }\end{array}$ & Removed \\
\hline $\begin{array}{l}\text { Before I share anything during class, I consider } \\
\text { whether it is appropriate for that moment. }\end{array}$ & $\begin{array}{l}\text { Even if not related to course content, I share what comes to } \\
\text { my mind during class. }\end{array}$ \\
\hline I try to understand the new subjects taught in class. & Removed \\
\hline I know what I have to do to succeed in a class. & When I fail a subject, I strive to improve it. \\
\hline $\begin{array}{l}\text { Even if I feel sleepy, I sleep after I complete my } \\
\text { homework. }\end{array}$ & $\begin{array}{l}\text { If I feel sleepy while I am studying, I'd rather stop studying } \\
\text { and sleep. }\end{array}$ \\
\hline Although it is tedious, I complete my homework. & Removed \\
\hline $\begin{array}{l}\text { My teachers warn me that I speak without } \\
\text { permission during class. }\end{array}$ & Removed \\
\hline $\begin{array}{l}\text { If there is anything I have to do about school, even } \\
\text { though I am not willing to do it, I do it first. }\end{array}$ & Removed \\
\hline $\begin{array}{l}\text { I prefer the easiest one when the teacher gives us } \\
\text { options. }\end{array}$ & Removed \\
\hline While reading, I become distracted easily. & Removed \\
\hline $\begin{array}{l}\text { Even if I have trouble understanding the subject of } \\
\text { the lesson, I compel myself to understand. }\end{array}$ & $\begin{array}{l}\text { Even if it is hard to comprehend the subject in class, I } \\
\text { compel myself to grasp it. }\end{array}$ \\
\hline I believe I can succeed if I study hard enough. & I work hard enough to obtain high marks from exams. \\
\hline I annoy my friends or teachers during class. & Removed \\
\hline \multirow[t]{3}{*}{ I remember the exam dates. } & I forget the exam dates. \\
\hline & $\begin{array}{l}\text { Although I have an important test the next day, I deal with a } \\
\text { pleasure-giving activity rather than studying. }\end{array}$ \\
\hline & $\begin{array}{l}\text { Before the exams, I begin studying without anybody } \\
\text { reminding me to do that. }\end{array}$ \\
\hline
\end{tabular}

The second trial form of the scale, which contains 21 items, was applied to the second study group consisting of $5^{\text {th }}-8$ th grade secondary school students. During this application, it was observed that some 5th graders had difficulty in understanding some statements in the form. Therefore, in later applications, 5th graders were removed from the application, and the scale was administered to 6th, 7th and 8th graders who represented the 11-14 age group. Therefore, the third study group $(N=210)$, to which PCA was applied, and the fourth study group $(N=297)$, to which CFA was applied, included 6th, 7 th and 8th graders. The 21-item form of the scale was applied to the third study group $(N=210)$ with which PCA was conducted. At this stage, items with low factor loadings or cross-loadings were removed from the scale. Thus, the final form of the ASCS with 12 items was developed. 
The ASCS consists of 12 items in two subscales based on a 5-point Likert-type response format, rated from "never" to "always". There are reverse coded items on scale, and the total score obtainable from the scale ranges from 12 to 60 . A higher score received from the scale shows higher academic selfcontrol. The fourth study group $(N=297)$ also completed the ASCS, the data from which were used to perform CFA. The PCA and CFA results are presented in detail in the findings section of the study.

\section{Data Analysis}

In this study, exploratory and confirmatory factor analyses were performed for construct validity. Principal component analysis was selected as the extraction method to reveal factor patterns of the ASCS, which allows easy interpretation, identification and reporting of results (Tabachnick \& Fidell, 2001). The PCA and varimax rotation were applied using SPSS 23.0 software (IBM Corp, 2015). A scree plot and the rule of eigenvalues greater than 1 (K1 rule) were used to determine the factor number. CFA was conducted to assess the validity of the hypothesized factor structure and identify the optimal model. Fit of the CFA model was evaluated with several fit indices including comparative fit index (CFI), non-normed fit index (NNFI) or called as Tucker Lewis index (TLI), root mean square error of approximation (RMSEA), and standardized root mean square residual (SRMR) using AMOS 19.0 software (Arbuckle, 2010). The maximum likelihood (ML) was chosen as an estimation method (Jöreskog \& Sörbom, 1993; Kline, 2005; Tabachnick \& Fidell, 2001). In terms of construct validity, the convergent validity of the measurement model was assessed by the Average Variance Extracted (AVE), which measures the explained variance of the construct.

In assessing reliability, Cronbach alpha (Cronbach, 1951) was used to determine the internal consistency. For the reliability of stability, the test-retest method was determined by Pearson product moment correlation coefficient. The Academic Perseverance Scale was used for criterion validity. It is a 5-item Likert-type rating scale consisting of 10 items and one dimension, developed to determine the academic perseverance levels of students between the ages 9 and 15. The scale was developed by Rojas, Usher and Toland (2012), and adapted to Turkish by Bozgün and Başgül (2018). Composite Reliability (CR) was also calculated for internal consistency. Expert opinion was sought for content validity.

Upon the recommendation of Tabachnick and Fidell (2001), to calculate suitability of the data set for parametric tests, adequacy of sample size, normality, missing data, outliers, and multicollinearity were checked. By means of that, the Kaiser-Meyer-Olkin (KMO) test was conducted for sample size; missing values were replaced using regression imputation and outliers were detected by modified $\mathrm{Z}$ score method. Univariate normality was checked by Skewness and Kurtosis values, histograms, and Q-Q plots. Correlation coefficients between items were controlled for multicollinearity (Table 3).

Table 3.

Means, standard deviations, and correlations of items

\begin{tabular}{lllllllllllllll}
\hline I & M & SD & $\begin{array}{l}\text { Item-total } \\
\text { correlation }\end{array}$ & i1 & i2 & i3 & i4 & i5 & i6 & i7 & i8 & i9 & i10 & i11 \\
\hline i1 & 4.27 & 0.89 & .563 & & & & & & & & & & & \\
i2 & 3.37 & 1.21 & .480 & .230 & & & & & & & & & & \\
i3 & 4.31 & 0.90 & .551 & .543 & .308 & & & & & & & & & \\
i4 & 4.13 & 1.05 & .435 & .339 & .269 & .338 & & & & & & & & \\
i5 & 3.86 & 1.27 & .485 & .328 & .297 & .344 & .295 & & & & & & & \\
i6 & 4.33 & 0.94 & .611 & .481 & .318 & .541 & .446 & .351 & & & & & & \\
i7 & 3.77 & 1.09 & .482 & .245 & .320 & .218 & .290 & .309 & .327 & & & & & \\
i8 & 4.08 & 1.16 & .534 & .488 & .186 & .399 & .274 & .319 & .449 & .367 & & & & \\
\hline i9 & 4.24 & 1.05 & .564 & .305 & .394 & .233 & .267 & .305 & .350 & .401 & .267 & & & \\
i10 & 3.91 & 1.31 & .358 & .316 & .189 & .251 & .124 & .266 & .244 & .142 & .299 & .205 & & \\
i11 & 4.01 & 1.27 & .510 & .250 & .367 & .266 & .198 & .270 & .336 & .336 & .290 & .475 & .200 & \\
i12 & 4.33 & 1.12 & .49 & .277 & .345 & .300 & .171 & .193 & .262 & .269 & .290 & .508 & .223 & .416 \\
\hline
\end{tabular}




\section{FINDINGS}

\section{Principal Component Analysis}

The study group $(N=210)$ for PCA consisted of $111(52.80 \%)$ male and $99(47.20 \%)$ female students. The average age of the group was $12.14(S D=.96)$. Assumptions necessary for the analysis were tested before running PCA. In terms of missing values, missing data less than 5\% was ignored based on the suggestion of Hair, Anderson, Tatham, and Black (2010). Six observations captured above 5\% were replaced using regression imputation. Variance Inflation Factor (VIF) value being lower than .10 (Kline, 2011), indicates that none of the independent variables were highly correlated, so there was no multicollinearity and singularity problem. Correlation coefficients between items were found to be between $.049-.500$. According to Pallant (2001), the ideal range of inter-item correlation is between .30 and .50 , and not over .70 . The data were analyzed by converting the outliers to standard $\mathrm{Z}$ scores. It is indicated that the acceptable range is \pm 4 in large samples $(n>100)$ for the data to be modified to $\mathrm{Z}$ scores (Mertler \& Vanatta, 2005). For this reason, data from a total of seven participants in the \pm 4 range in the data set were deleted.

The PCA processes were carried out by fixing the number of factors to two to adhere to the theoretical basis. In the PCA, the acceptance level for factor loading values is determined at .32 (Büyüköztürk, 2010). Items were evaluated by checking their eigenvalues and scree plot in terms of their factor loadings. Firstly, items with low factor loadings and cross-loading items with less than .10 difference in factor loadings were removed from the scale. There were 12 items left in the scale (Table 4).

Table 4.

Factor loadings of 12 items left in the ASCS

\begin{tabular}{|c|c|c|c|}
\hline No & Items & $\begin{array}{l}1^{\text {st }} \text { factor } \\
\text { (academic } \\
\text { perseverance) }\end{array}$ & $\begin{array}{l}2^{\text {nd }} \text { factor } \\
\text { (academic } \\
\text { attention) }\end{array}$ \\
\hline 4 & I work hard enough to obtain high marks from exams. & .806 & \\
\hline 12 & When I fail a subject, I strive to improve it. & .719 & \\
\hline 1 & I prepare for the exams by reviewing the subjects. & .715 & \\
\hline 5 & Even if it is hard to comprehend the subject in class, I compel myself to grasp it. & 669 & \\
\hline 9 & $\begin{array}{l}\text { If my friends invite me out while I am doing homework at home, I go out after I } \\
\text { complete it. }\end{array}$ & 613 & \\
\hline 13 & Even if my desk mate tries to make me chat, I pay attention to the lesson. & 607 & \\
\hline 2 & $\begin{array}{l}\text { When I am not interested in a subject during class, I find myself taking an interest in } \\
\text { something else. }\end{array}$ & .580 & \\
\hline 17 & Before the exams, I begin studying without anybody reminding me to do that. & .566 & \\
\hline 3 & My teachers warn me that I disrupt the class. & & .743 \\
\hline 15 & My friends say I act in a disturbing way during class. & & .706 \\
\hline 6 & I forget the exam dates. & & .665 \\
\hline 7 & Even if not related to course content, I share what comes to my mind during class. & & .620 \\
\hline \multicolumn{2}{|r|}{ Eigenvalue } & 3.59 & 2.05 \\
\hline \multicolumn{2}{|c|}{ Variance Explained } & 29.98 & 17.13 \\
\hline \multicolumn{2}{|c|}{ Total Variance Explained } & \multicolumn{2}{|c|}{47.11} \\
\hline
\end{tabular}

According to the results, in the first factor there were eight items and four items in the second one. Each item was only loaded on one factor and these loadings were higher than .50. The first factor (academic perseverance) explains $29.98 \%$ of the total variance while this is $17.13 \%$ for the second factor (academic attention). Both factors explain $47.11 \%$ of the total variance together. A ratio of total variance between 40 and 60 percent is ideal (Scherer, Luther, Wiebe, \& Adams, 1988), so the total variance ratio of the ASCS explained by the two factors is acceptable.

\section{Confirmatory Factor Analysis}

In order to confirm the 12-item 2-factor model, CFA was performed with data from 297 students. Of the study group, $150(50.51 \%)$ were female and 144 (48.48\%) were male. Three students $(1.01 \%)$ did not report their gender. Ages of the students in the study group ranged from 11 to $14(\mathrm{M}=12.92 ; \mathrm{SD}=$ 
0.97). As an estimation method Maximum Likelihood (ML) was chosen. Prior to analysis, multivariate normality as an assumption for ML was controlled. Skewness and kurtosis values calculated for each item were between -2 and +2 and that indicated normal distribution (George \& Mallery, 2010). The visual inspection of histogram and Q-Q plots were also observed.

Examining the goodness of fit indices in the first run of CFA, it is observed that The Root Mean Square Error of Approximation (RMSEA) value was .073, The Comparative Fit Index (CFI) value was.90, the Standardized Root Mean Square Residuals (SRMR) value was found .06 and the Non-Normed Fit Index (TLI) value was.88. Rather than TLI all values can be acceptable (Jöreskog \& Sörbom, 1993; Kline, 2005; Marcoulides \& Schumacher, 2001). Nevertheless, by checking the modification indices, the fit could be improved when four items from academic perseverance factor were correlated. The first item "I prepare for the exams by reviewing the subjects." was covaried with item three "My teachers warn me that I disrupt the course.", and item three was covaried with item six "I forget the exam dates.". After the second run of CFA the results refer to adequate fit (Table 5).

Table 5.

The model fit indices used for CFA

\begin{tabular}{lllll}
\hline \multirow{2}{*}{ Model Fit Index } & \multicolumn{2}{c}{ Acceptable Fit } & \multirow{2}{*}{ Sample Statistics } & \multirow{2}{*}{ Decision } \\
\cline { 2 - 5 } & Moderate Fit & Good Fit & & \\
\hline CFI & $.90-.95$ & $.95-1.00$ & .93 & Moderate \\
TLI & $.85-.90$ & $.90-1.00$ & .91 & Good \\
RMSEA & $.05-.08$ & $\leq .05$ & .065 & Moderate \\
SRMR & $.05-.08$ & $\leq .05$ & .05 & Good \\
\hline
\end{tabular}

Additionally, $t$ values for the standardized coefficients for each item varied between 7.94 and 11.65. $t$ values calculated for all items were found to be significant at $p<.01$ level. It was observed that the error variances of items were low (Figure 1).

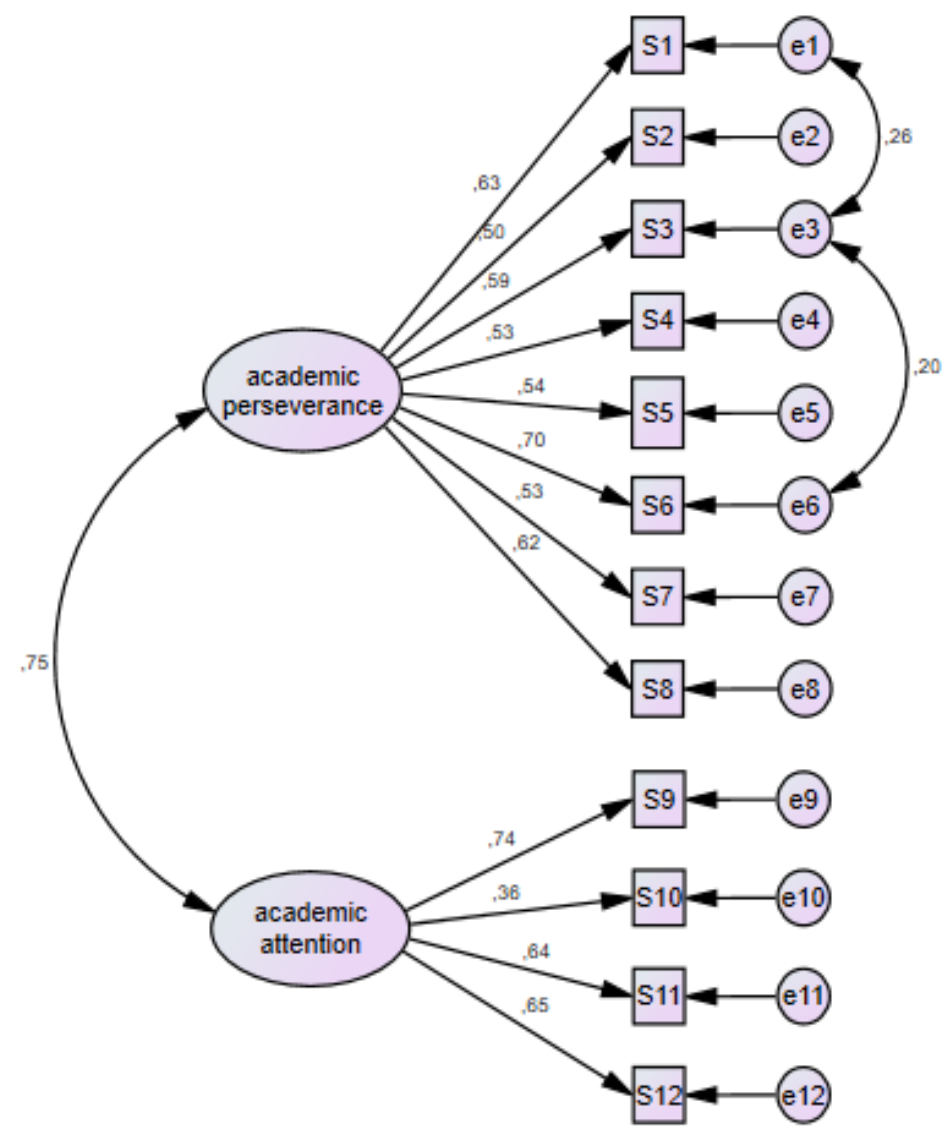

Figure 1. Standardization coefficients of the ASCS items 
As seen in Figure 1, the standardized factor loadings varied between .50 and .70 for the academic perseverance factor and between .36 and .74 for the academic attention factor. It can be said that all items had a significant contribution to the model. Also, R-squared values changed between .128 and .541 .

The Academic Perseverance Scale (Bozgün \& Başgül, 2018) was used to determine the criteria validity of the ASCS. Data were collected from 120 students (51.27\% female and $48.73 \%$ male) for the criteria validity study. The average of the students was $12.54(S D=.91)$. Cronbach's alpha internal consistency coefficient in the original form of the scale was calculated as .85, as .84 in the adaptation study, and as .88 in this study. The correlation between the total score of the Academic Perseverance Scale and the total score of the ASCS was found to be .74, and was found to be .71 and .46, respectively, for the academic perseverance and academic attention sub-scale scores $(p<.01)$. A high positive correlation was found between the total scores from the Academic Perseverance Scale and the "academic perseverance" factor, while a positive, but moderate relationship was found with the "academic attention" factor.

In terms of construct validity, convergent validity was examined by calculating AVE. It was observed that the factors' AVE values were respectively .83 and .80. Based on the suggestion of Hair et al (2010) for AVE is that .50 or higher suggest good validity. Thus, it can be said that the AVE values for both factors were acceptable.

\section{Reliability}

To determine internal consistency, the Cronbach's alpha coefficients were computed for each factor and for the 12-item two-factor model. The Cronbach alpha coefficient was found as .81 for the entire scale, .81 for the academic perseverance factor, and .64 for the academic attention factor. The reliability coefficient for test-retest reliability, which was evaluated by applying the scale to 54 participants at an interval of four weeks (51.85\% female, $48.15 \%$ male, average age $12.52(S D=.90)$, was calculated as .93 for the entire scale, and it was found to be .89 , and .91 , respectively, in the academic perseverance and academic attention factors $(p<.01)$. As a result of Composite Reliability (CR) coefficients of the factors were calculated for academic perseverance factor .80; for academic attention factor .70. The threshold for CR is suggested from .60 and up (Brunner \& Süß, 2005).

\section{DISCUSSION AND CONCLUSION}

In this study, the aim was to develop an instrument to measure self-control skills shown by secondary school students while they are trying to meet the demands and expectations of academic life. According to the literature, the demands and expectations of academic life are mostly related to participation in the classes, following the courses, preparing for exams and doing assignments. Considering the theoretical framework of the research study, academic perseverance and academic attention were determined as the two dimensions of the academic self-control concept. The academic attention dimension refers to the dilemma a student experiences when faced with an academic challenge which requires self-control. Accordingly, academic attention involves self-awareness, ability to focus attention, to delay gratification and to resist temptations. The other dimension of academic self-control, defined as academic perseverance, is the ability to follow through, plan, take responsibility and persevere after becoming aware of the dilemmas and to resist them.

As a result of individual and group interviews with secondary school students and teachers, behavioral indicators in three contexts - class, exams and assignments-were determined by considering two dimensions, and thereby an item pool was created. After receiving expert opinion and following two trial applications, the final form of items was created, and the main application took place. Structural validity of the scale was supported by PCA. After examining the items in terms of cross-loadings, it was 
observed that the ASCS consisted of a total of 12 items with two factors. It was found that the variance explained by the scale was $47.11 \%$. Variance explained between $40 \%$ and $60 \%$ is accepted as adequate for social sciences (Scherer et al, 1988). The factor structure found in PCA was verified by CFA analysis. As a result of CFA, the model fit indices were found to be within acceptable limits, and no modification was required. As a result of the studies conducted for criteria validity, the Academic Perseverance Scale was used and its scores showed meaningful relationships in a positive direction with academic selfcontrol scores. For convergent validity AVE was calculated, and the results were found acceptable. Internal consistency coefficients for reliability were found to show high reliability for the whole scale and for the academic perseverance factor $(.81<\alpha<.00)$, and moderate reliability for the academic attention factor $(.61<\alpha<.80)$ (Özdamar, 2013). The reason why the reliability level of the academic attention factor is relatively low could be attributed to the limited number of items in this factor (four items), and also to the potentially changeable nature of these items' reference for one course to another. It is also worth indicating the various types of the term "attention" and its cognitive characteristic. Also, $\mathrm{CR}$ scores used for the reliability of the measurement were acceptable.

Results obtained from the test-retest analysis indicated that the scale is largely stable. During the trial applications, the reason behind some of the 5th graders having difficulty in understanding the statements of the scale was discussed by reference to the idea that their developmental reading and comprehension skills level was not suitable for that scale. Therefore, this age group was eliminated from the main application. It is suggested that this group should be included in academic self-control studies with primary school students.

In conclusion, it can be suggested that the ASCS, consisting of 12 items and two factors, is a suitable measurement tool that can be used to evaluate academic self-control skills of 6th, 7th and 8th graders. Having academic self-control skills is an important variable that contributes to students' academic achievements. These skills can be developed indirectly through families and schools or directly with programs that include some cognitive and behavioral strategies. The secondary school period is critical in self-control development. In this respect, using this measurement tool in studies investigating academic self-control and in programs towards improving self-control in secondary school students will serve the purpose and play an important role.

\section{Acknowledgements}

This study is based on a $\mathrm{PhD}$ dissertation titled "A Parental Guidance: Improving Academic SelfControl in Adolescence", Ankara University, Institute of Educational Sciences.

\section{REFERENCES}

Arbuckle, J. L. (2010). Amos (Version 19.0) [Computer Program]. Chicago: SPSS.

Arnesen, T., Elstad, E., \& Christophersen, T. A. (2017). How Finnish and Swedish learners' academic self-control relates to time spent online in class, perceptions of educator qualities, and school appreciation: A crosssectional comparison. Educational Science, 7, 68. DOI: 10.3390/educsci7030068

Bandura, A. (1977). Self-efficacy: Toward a unifying theory of behavioral change. Psychological Rewiev, 84(2), 191-215. DOI: 10.1037/0033-295X.84.2.191

Baumeister, R. F. (2002). Yielding to temptation: Self-control failure, impulsive purchasing and consumer behavior. Journal of Consumer Research, 28(4), 670-676. DOI: 10.1086/338209

Baumeister, R. F., \& Vohs, K. D. (2007). Self-regulation, ego depletion and motivation. Social and Personality Psychology Compass, 1(1), 115 - 128. DOI: 10.1111/j.1751-9004.2007.00001.x

Blakemore, S. J., den Ouden, H., Choudhury, S., \& Frith, C. (2007). Adolescent development of the neural circuitry for thinking about intentions. Social Cognitive and Affective Neuroscience, 2, 130-139. DOI: 10.1093/scan/nsm009

Bozgün, K., \& Başgül, M. (2018). Akademik azim ölçeğinin Türkçe’ye uyarlanması: Geçerlik ve güvenirlik çalışması. [Adaptation of academic grit scale to Turkish: Validity and reliability study]. Akademik Sosyal Araştırmalar Dergisi, 6(85), 435-445. DOI: 10.16992/ASOS.14521 
Bridgett, D. J., Burt, N. M., Edwards, E. S., \& Deater-Deckard, K. (2015). Intergenerational transmission of selfregulation: A multidisciplinary review and integrative conceptual framework. Psychological Bulletin, 141(3), 602-654. DOI: $10.1037 / \mathrm{a} 0038662$

Brunner, M. \& Süß, H. (2005). Analyzing the reliability of multidimensional measures: An example from intelligence research. Educational and Psychological Measurement, 65(2), 227-240. DOI: $10.1177 / 0013164404268669$

Büyüköztürk, Ş. (2010). Sosyal bilimler için çok değişkenli istatistik. [Multivariate statistics for social sciences]. Ankara: Pegem A Yayıncılık.

Casey, B., \& Caudle, K. (2013). The teenage brain: Self-control. Current Directions in Psychological Science, 22(2), 82-87. DOI: $10.1177 / 0963721413480170$

Cauffman, E., Steinberg, L., \& Piquero, A. (2005). Psychological, neuropsychological, and psychophysiological correlates of serious antisocial behavior in adolescence: The role of self-control. Criminology, 43, 133-176. DOI: 10.1111/j.0011-1348.2005.00005.x

Cho, Y. I., Kim, J. S., \& Kim, J. O. (2018). Factors influencing adolescents' self-control according to family structure. Journal of Child and Family Studies, 27(11), 3520-3530. DOI: 10.1007/s10826-018-1175-4

Cronbach, L. J. (1951). Coefficient alpha and the internal structure of tests. Psychometrika, 16, 297-334. DOI: 10.1007/BF02310555

DeVellis, R. F. (2017). Scale development: Theory and applications. Tarık Totan (Ed). Ankara: Nobel Akademi Yayıncilik.

Duckworth, A. L., \& Seligman, M. (2017). The science and practice of self-control. Perspectives on Psychological Science, 12(5), 715-718. DOI: 10.1177/1745691617690880

Duckworth, A. L., Gendler, T. Z., \& Gross, J. J. (2014). Self-control in school-age children, Educational Psychologist, 49(3), 199-217. DOI: 10.1080/00461520.2014.926225

Duckworth, A. L., Taxer, J. L., Eskreis-Winkler, L., Galla, B. M., \& Gross, J. J. (2019). Self-control and academic achievement. Annual Review Psychology, 70, 373-399. DOI: 10.1146/annurev-psych-010418-103230

Durmaz, M. (2012). Ortaöğretim ögrencilerinin (10. sınıf) temel psikolojik ihtiyaçlarının karşılanmışlık düzeyleri, motivasyon ve Matematik kaygisı arasındaki ilişkilerin belirlenmesi. [Identifying the relationships among the degrees of basic pyschological needs satisfaction, motivation and Mathematics anxiety of high school students (10th grade)]. (Unpublished master's thesis). Abant İzzet Baysal University, Institute of Educational Sciences, Bolu.

George, D. \& Mallery, M. (2010). SPSS for Windows step by step: A simple guide and reference, 17.0 update (10a ed.) Boston: Pearson.

Gottfredson, M. R., \& Hirschi, T. (1990). A general theory of crime. Stanford University Press.

Gross, J. J., \& Thompson, R. A. (2007). Emotion regulation: Conceptual foundations. In J. J. Gross (Ed.), Handbook of emotion regulation (pp. 3-23). New York, NY: Guilford.

Hair, J. F., Anderson, R. E., Tatham, R. L., \& Black, W. C. (2010). Multivariate data analysis (7th ed.). Upper Saddle River, NJ: Prentice Hall, Inc.

IBM Corp. (2015). IBM SPSS Statistics for Windows (Version 23.0). Armonk, NY: IBM Corp.

Jackson, D. L., Gillaspy, J. A., \& Purc-Stephenson, R. (2009). Reporting practices in confirmatory factor analysis: An overview and some recommendations. Psychological Methods, 14, 6-23. DOI: 10.1037/a0014694

Jöreskog, K. G., \& Sörbom, D. (1993). LISREL 8: Structural equation modeling with the SIMPLIS command language. Chicago: Scientific Software International.

Kapıkıran, Ş. (2012). Validity and reliability of the academic resilience scale in Turkish high school. Education, $132,474-483$.

Karasar, N. (2004). Bilimsel araştırma yöntemi [Scientific research method]. (15. edition). Ankara: Nobel Yayın Dağıtım.

Kennett, D. J. (1994). Academic self-management counselling: preliminary evidence for the importance of learned resourcefulness on program success. Studies on Higher Education, 19(3), 295-307.

Kennett, D. J., \& Keefer, K. (2006). Impact of learned resourcefulness and theories of intelligence on academic achievement of university students: An integrated approach. Educational Psychology, 26, 441-457. DOI:10.1080/01443410500342062

Kennett, D. J., \& Reed, M. J. (2009). Factors influencing academic success and retention following a 1st-year postsecondary success course. Educational Research and Evaluation, 15, 153-166. DOI: $10.1080 / 13803610902804382$

Kennett, D. J., Reed, M. J., \& Stuart, A. S. (2013). The impact of reasons for attending on academic resourcefulness and adjustment. Active Learning in Higher Education, 14(2), 123-133. DOI: 10.1177/1469787413481130

Kline, T. J. B. (2005). Psychological testing: A practical approach to design and evaluation. Thousand Oaks: Sage.

Marcoulides, G., \& Schumacher, R. (2001). New developments and techniques in structural equation modelling. London: Lawrence Erlbaum. 
Martin, A. J., \& Marsh, H. W. (2006). Academic resilience and its psychological and educational correlates: A construct validity approach. Psychology in the Schools, 43(3), 267-281. DOI: 10.1002/pits.20149

Martin, R. D., \& Kennett, D. J. (2018). To be kind or not to be kind: The moderating role of self-compassion in the relationship between general resourcefulness and academic self-regulation. The Journal of Social Psychology, 158(5), 626-638. DOI: 10.1080/00224545.2017.1407286

Martin, R. D., Kennett, D. J., \& Hopewell, N. (2019). Examining the importance of academic-specific selfcompassion in the academic self-control model. The Journal of Social Psychology, 159, 1-16. DOI: $10.1080 / 00224545.2018 .1555128$

Mertler, C. A., \& Vannatta, R. A. (2005). Advanced and multivariate statistical methods: Practical application and interpretation. 3rd Edition, Pyrczak, Los Angeles.

Ministry of National Education (2017). Press briefing report of Council on Education and Training. Ankara: Author. Retrieved from http://ttkb.meb.gov.tr/meb_iys_dosyalar/2017_07/18160003_basin_aciklamasi program.pdf

Mischel, W. (1981). Metacognition and the rules of delay. In J. H. Flavell, \& L. Ross (Eds.), Social cognitive development: Frontiers and possible futures (pp. 240-272). New York, NY: Cambridge University Press.

Mortimore, P. (1993). School effectiveness and the management of effective learning and teaching. School Effectiveness and School Improvement, 4, 290-310. DOI: 10.1080/0924345930040404

Nebioğlu, M., Konuk, N., Akbaba S., \& Eroğlu, Y. (2012). The investigation of validity and reliability of the Turkish version of the brief self-control scale. Klinik Psikofarmakoloji Bülteni, 22(4), 340-351. DOI: 10.5455/bcp.20120911042732

Oriol, X., Miranda, R., Oyanedel, J. C., \& Torres, J. (2017). The role of self-control and grit in domains of school success in students of primary and secondary school. Frontier Psychology, 8:1716. DOI: 10.3389/fpsyg.2017.01716

Öncü, H. (2012). Akademik özyeterlik ölçeğinin Türkçe’ye uyarlanması. [Adaptation of academic self-efficacy scale into Turkish]. Ahi Evran Üniversitesi Kırşehir Eğitim Fakültesi Dergisi (KEFAD), 13(1), 183-206.

Özdamar, K. (2013) Paket programlar ile istatistiksel veri analizi. [Statistical data analysis with package programs]. (Vol. 1). Ankara: Nisan Kitabevi.

Pallant, J. (2001). SPSS Survival manual: A step by step guide to data analysis using SPSS for windows version 10. Buckingham: Open University Press.

Rosenbaum, M. (1980). A schedule for assessing self-control behaviors: Preliminary findings. Behavior Therapy, 11(1), 109-21. DOI: 10.1016/S0005-7894(80)80040-2

Rosenbaum, M. (1990). The role of learned resourcefulness in the self-control of health behavior. In M. Rosenbaum (Ed.), Learned resourcefulness: On coping skills, selfcontrol, and adaptive behavior (pp. 330). New York: Springer Publishing Co.

Rosenbaum, M. (2000). The self-regulation of experience: Openness and construction. In P. Dewe, A. M., Leiter, \& T. Cox (Eds.), Coping, health and organizations (pp. 51-67). London: Taylor \& Francis.

Ryan, R. M., \& Connell, J. P. (1989). Perceived locus of causality and internalization: Examining reasons for acting in two domains. Journal of Personality and Social Psychology, 57(5), 749-761. DOI: 10.1037/00223514.57.5.749

Ryan, R. M., \& Deci, E. L. (2000). Self-determination theory and the facilitation of intrinsic motivation, social development, and well-being. American Psychologist, 55(1), 68. DOI: 10.1037/0003-066X.55.1.68

Sarıçam, H. (2014). Psychometric properties of the academic locus of control scale-adolescent form. Elementary Education Online, 13(4), 1135-1144. DOI: 10.17051/io.2014.32429

Scherer, R. F., Wiebe, F. A., Luther, D. C., \& Adams, J. S. (1988). Dimensionality of coping: Factor stability using the ways of coping questionnaire, Psychological Reports, 62(3), 763-770. DOI: 10.2466/pr0.1988.62.3.763

Steinberg, L. (2008). A social neuroscience perspective on adolescent risk-taking. Developmental Review, 28(1), 78-106. DOI: 10.1016/j.dr.2007.08.002

Tabachnick, B.G., \& Fidell, L.S. (2001). Using multivariate statistics. 4th Edition, Allyn and Bacon, Boston.

Tangney, J. P., Baumeister, R. F., \& Boone, A. L. (2004). High self-control predicts good adjustment, less pathology, better grades, and interpersonal success. Journal of Personality and Social Psychology, 72(2), 271-324. DOI: 10.1111/j.0022-3506.2004.00263.x

UNESCO. (2020). COVID-19 educational disruption and response. Retrieved from https://en.unesco.org/covid19/educationresponse. 


\section{APPENDIX 1}

\section{Academic Self-Control Scale (in English)}

The "course" word represents all the courses at school.

\begin{tabular}{|c|c|c|c|c|c|c|}
\hline 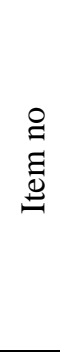 & Academic Self-Control Scale & 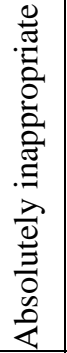 & 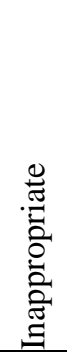 & 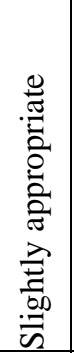 & 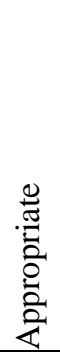 & 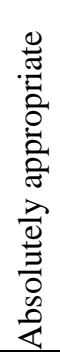 \\
\hline 1 & I prepare for the exams by reviewing the subjects. & & & & & \\
\hline 2 & $\begin{array}{l}\text { When I am not interested in a subject during class, I find myself taking an } \\
\text { interest in something else }\end{array}$ & & & & & \\
\hline 3 & My teachers warn me that I disrupt the course. & & & & & \\
\hline 4 & I work hard enough to obtain high marks from exams. & & & & & \\
\hline 5 & $\begin{array}{l}\text { Even if it is hard to comprehend the subject in class, I compel myself to } \\
\text { grasp it. }\end{array}$ & & & & & \\
\hline 6 & I forget the exam dates. & & & & & \\
\hline 7 & $\begin{array}{l}\text { Even if not related to course content, I share what comes to my mind during } \\
\text { class. }\end{array}$ & & & & & \\
\hline 8 & $\begin{array}{l}\text { If my friends invite me out while I am doing homework at home, I go out } \\
\text { after I complete it. }\end{array}$ & & & & & \\
\hline 9 & When I fail a subject, I strive to improve it. & & & & & \\
\hline 10 & $\begin{array}{l}\text { Even if my desk-mate tries to make me chat, I pay my attention to the } \\
\text { lesson. }\end{array}$ & & & & & \\
\hline 11 & My friends say I act out in a disturbing way during class. & & & & & \\
\hline 12 & $\begin{array}{l}\text { Before the exams, I begin studying without anybody reminding me to do } \\
\text { that. }\end{array}$ & & & & & \\
\hline
\end{tabular}




\section{TÜRKÇE GENIŞLETILMIŞ ÖZET}

"Öz denetim” kavramı bireyin davranışını değiştirmek için gereken bilinçli çabayı ifade eder, böylece yaşanılan çelişki azalır (Baumeister \& Vohs, 2007). Yaşamın farklı alanlarında- sağlık, akademik, bağımlılıklar, işle ilgili ya da psikolojik iyi olma halinde- öz denetimin etkisi bulunur. Akademik alanda gösterilen öz denetim, akademik öz denetim olarak ifade edilir. Kennett (1994) tarafindan ayrıca akademik özkaynak olarak da tanımlanan akademik öz denetim davranışları sebat etmeyi, kendini çok çalışmaya vermeyi, anlık hazzı ertelemeyi, zamanı etkili kullanmayı, planlama ve problem çözme stratejilerine başvurmayı ve stres ve akademik zorlukları yönetmek için kendinle olumlu konuşma gibi etkili baş etme tekniklerini kullanmayı içerir (Kennett \& Keefer, 2006).

Alanyazın göstermektedir ki, okullarda can sıkıntısına katlanabilerek dersi daha dikkatli dinleyen, ders sırasında arkadaşıyla konuşma isteğini bastırabilen, ödev yapma ve sınava hazırlanma konusunda daha titiz davranan, planlı ve hedefi olan öğrenciler akranlarına göre daha yüksek notlar almaktadırlar (Nebioğlu, Konuk, Akbaba, \& Eroğlu, 2012; Tangney et al, 2004; Duckworth et al, 2019, Martin et al, 2019).

$\mathrm{Bu}$ araştırmanın temel amacı, 11-14 yaş aralığındaki öğrencilerin akademik öz denetim becerilerini ölçmek için güvenilir ve geçerli bir ölçme arac1 geliştirmektir. Orta okul dönemi hem çocuklukla ergenlik arasında gelişimsel bir basamak olarak değerlendirildiğinde ergeni risklerden korumak için, hem de öğrencinin kendisi için uygun bir lise tercihi yapmasının önemi göz önüne alındığında akademik değeri bakımından akademik öz denetimin geliştirilmesi için kritik bir değere sahiptir. Ancak alanyazın incelendiğinde ortaokul öğrencilerinin akademik öz denetimini ölçmeye yönelik herhangi bir araca rastlanmamıştır.

Akademik öz denetimin ölçülmesi, bu becerinin geliştirilmesine yönelik bireysel ya da grup müdahale programlarının geliştirilmesine ve etkililiğinin araştırılmasına, uzun erimde de akademik başarının artmasına katkı sunabilir. Bununla birlikte, akademik öz denetimin güçlendirilmesinin yalnızca öğrenci için değil aynı zamanda eğitim sürecinde gerçekleşen tüm öğrenmelere yönelik olumlu çıtıları olabilir. Dolayısıyla, ortaokul öğrencilerinin akademik yaşamın beklenti ve taleplerini karşılarken ortaya koydukları öz denetim becerilerini ölçebilecek bir ölçme aracına ihtiyaç duyulmaktadır.

$\mathrm{Bu}$ araştırmanın çalışma grubunda tamamı 2019-2020 öğretim yılında Ankara İli’nde üç farklı devlet ortaokulunda öğrenim gören 545'i (\%50.14) kız, 539'u (\%49.59) erkek ve cinsiyetini belirtmeyen üç öğrenci (\%0.27) olmak üzere toplam 1087 öğrenci yer almaktadır. Araştırma kapsamında esas uygulama öncesi iki deneme uygulaması yapılmıştır.

Alanyazın incelemesi ve saha çalı̧̧anlarıyla yapılan görüşmeler ve gözlemler sonucunda değişkene ilişkin iki boyut- akademik dikkat ve akademik sebat- belirlenmiş; bu boyutlar sınıf ortamı, ödev ve sınavlar olmak üzere üç farklı ortamda ele alınmıştır. Boyutların bu ortamlara ilişkin bileşenleri belirlenerek madde havuzu oluşturulmuş ve kapsam geçerliği kapsamında uzman görüşüne başvurulmuştur. Elde edilen 54 maddelik deneme formu ilk çalışma grubuna $(\mathrm{N}=350)$ uygulanmış, elde edilen veriler kullanılarak ölçeğin madde toplam korelasyonları ve faktör yapısı incelenmiştir. İnceleme sonucu elde edilen ölçeğin 21 maddelik ikinci deneme formu ikinci çalışma grubuna $(\mathrm{N}=230)$ uygulanmıştır. Bu uygulamalar sırasında özellikle küçük yaştaki bazı 5. sınıf öğrencilerinin soruları anlamakta zorlandıkları gözlenmiştir. Bu nedenle daha sonraki uygulamalarda 5. sınıf öğrencileri uygulamadan çıkarılarak çalışmalara 11-14 yaş grubunu temsil eden 6.,7. ve 8. sinıf öğrencileri ile devam edilmiştir. Esas uygulamada 21 maddelik form kullanılmıştır.

Analizler öncesi veri setinin parametrik analizlere uygunluğunu değerlendirmek için analizler öncesi varsayımlar test edilmiştir. Bu kapsamda Kaiser-Meyer-Olkin (KMO) testi ile örneklem büyüklüğü, normallik basıklık çarpıklık, histogram grafiği ve Q-Q plot ile, çoklu bağlantı problemi ve tekillik için 
madde çiftleri arası korelasyon katsayıları incelenmiştir. Uç değer ayıklaması $Z$ puanları dönüştürülerek, kayıp veriler ise regresyon atama ile yapılmıştır (Kline, 2005; Tabachnick \& Fidell, 2001). Ölçeğin iç güvenirliği için Cronbach Alfa hesaplanmıştır. Ölçüt geçerliği için Akademik Azim Ölçeği (Bozgün \& Başgül, 2018) kullanılmıştır.

TBA için çalışma grubunu ( $\mathrm{N}=210), 111(\% 52.80)$ erkek ve 99 (\%47.20) kız öğrenci oluşturmaktadır. Grubun yaş ortalaması 12.14 'tür $(\mathrm{SS}=.96)$. TBA sonuçları, ölçeğin, akademik sebat ve akademik dikkat olmak üzere iki boyut ve 12 maddeden oluşan bir yapı gösterdiğini ortaya koymaktadır. Akademik sebat boyutu sekiz maddeden oluşmaktadır ve açıkladığ 1 varyans \%29.98'dir. Akademik dikkat alt boyutu dört maddeden oluşmakta ve varyansın \% 17.13'ünü açıklamaktadır. Faktörlerin açıkladığ 1 toplam varyans $\% 47.11$ 'dir.

DFA için 150'si (\%50.51) kız, 144'ü (\%48.48) erkek ve cinsiyetini belirtmeyen üç (\%1.01) olmak üzere toplam 297 öğrenciden veri toplanmıştır. Çalışma grubundaki öğrencilerin yaşları 11-14 arasında değişmektedir, grubun yaş ortalamas1 12.92, standart sapması 0.97'dir. DFA sonucu Uyum İyiliği değerleri incelendiğinde; Yaklaşık Hataların Ortalama Karakökü (RMSEA) değeri .073, Karşılaştırmalı Uyum İndeksi (CFI) değeri .91, Normlaştırılmamış Uyum İndeksi (TLI) .88 ve Standardize Edilmiş Artık Ortalamaların Karekökü (SRMR) değeri .06 bulunmuştur. Modifikasyon önerileri incelenerek birinci faktörde 1 . ve 3. madde, 3. ve 6. maddeler arasında kovaryans kurularak modelin uyumu arttırılmıştır (RMSEA $=.065, \mathrm{CFI}=.93, \mathrm{TLI}=.91, \mathrm{SRMR}=.05)$. AÖDÖ'nin elde edilen uyum indeks değerlerine bakıldığında ölçeğin yeterli uyum gösteren bir yapıda olduğu belirtilebilir (Marcoulides ve Schumacher, 2001). Bu nedenle herhangi bir modifikasyona gerek duyulmamıştır. DFA'ya ilişkin her bir maddeye ait standardizasyon katsayıları .36 ile .74 arasındadır. Standardizasyon katsayılarının anlamlı olup olmadığını belirlemek için belirlenen t değerleri 7.94 ile 11.65 değerleri arasında değişmektedir ve tüm maddeler için $\mathrm{p}<.01$ düzeyinde anlamlı bulunmuştur.

AÖDÖ’nin ölçüt geçerliğini belirlemek amacıyla 9-15 yaş aralığındaki öğrencilerin akademik azim düzeylerini belirleyebilmek amacıyla geliştirilmiş, 10 madde ve tek boyuttan oluşan Akademik Azim Ölçeği (Bozgün ve Başgül, 2018) kullanılmıştır. Ölçüt geçerliği çalışması için 120 öğrenciden (\%51.27'si kı, \%48.73'ü erkek) veri toplanmıştır. Akademik Azim Ölçeği toplam puanı ile AÖDÖ toplam puanı arasındaki korelasyon .74, akademik sebat ve akademik dikkat alt boyut puanları için sırasıyla .71 ve .46 bulunmuştur $(\mathrm{p}<.01)$. İç tutarlılı̆g 1 belirlemek için hesaplanan Cronbach Alfa katsayıs1 tüm ölçek için .81, "akademik sebat" boyutu için .81, "akademik dikkat" boyutu için ise .64 olarak bulunmuştur. Ölçeğin dört hafta arayla 54 katılımcıya $(\% 51.85$ 'i kız, \%48.15'i erkek, yaş ortalamas1 12,52 ( $\mathrm{SS}=.90)$ uygulanması ile değerlendirilen test tekrar test güvenirliğine ilişkin güvenirlik katsayısı tüm ölçek için .93 olarak, akademik sebat ve akademik dikkat alt ölçeklerinde ise sırası ile .89 , ve .91 olarak hesaplanmıştır $(\mathrm{p}<.01)$.

Sonuç olarak, analiz bulgularına göre 12 madde ve iki boyuttan oluşan AÖDÖ'nin 6., 7. ve 8. sınıf öğrencileri için akademik öz denetim becerisini ölçmek amacıyla kullanılabilecek uygun bir ölçme aracı olduğu belirtilebilir. Akademik öz denetim becerilerine sahip olmak öğrencilerin akademik başarılarına katk1 sağlayan önemli bir bileşendir. Bu beceriler kimi bilişsel ve davranışsal stratejilerle doğrudan öğrencilere uygulanacak programlarla, dolaylı olarak da aileler ve okul aracılığıyla geliştirilebilir. Ortaokul dönemi öz denetim gelişiminde kritik bir öneme sahiptir. Bu bakımdan 11-14 yaş aralığındaki ortaokul öğrencilerinin akademik öz denetimlerinin daha iyi anlaşılması, değerlendirilmesi ve geliştirilmesine yönelik tüm çalışma ve araştırmalarda bu ölçme aracının kullanılması alandaki ihtiyacı giderecektir. 


\section{EK 1}

\section{Akademik Öz Denetim Ölçeği (Türkçe)}

“Ders” sözcügünün geçtiği maddeler genel anlamda tüm dersler düşünülerek değerlendirilmelidir.

\begin{tabular}{|c|c|c|c|c|c|c|}
\hline \begin{tabular}{l}
0 \\
$z$ \\
0 \\
\multirow{z}{*}{} \\
$\Sigma$
\end{tabular} & Akademik Öz Denetim Ölçeği & 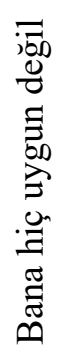 & 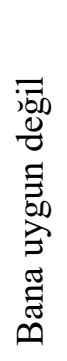 & 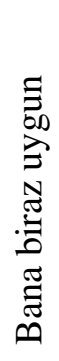 & 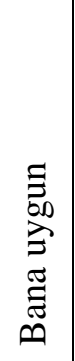 & 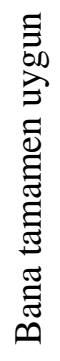 \\
\hline 1 & Sınavlardan önce konuları tekrar ederek hazırlık yaparım. & & & & & \\
\hline 2 & $\begin{array}{l}\text { Derste işlenen konu ilgimi çekmediği zaman kendimi başka bir } \\
\text { şeyle ilgilenirken bulurum. }\end{array}$ & & & & & \\
\hline 3 & Öğretmenlerim beni dersin işlenişini bozduğum için uyarır. & & & & & \\
\hline 4 & Sınavlardan yüksek not almak için yeterince çalışırım. & & & & & \\
\hline 5 & Derste işlenen konu zor olsa bile anlamak için kendimi zorlarım. & & & & & \\
\hline 6 & Sinav tarihlerini unuturum. & & & & & \\
\hline 7 & Dersle ilgili olmasa bile aklıma gelen şeyi ders sırasında söylerim. & & & & & \\
\hline 8 & $\begin{array}{l}\text { Evde ödev yaparken arkadaşlarım beni dışarı çağırırsa ödevimi } \\
\text { bitirince çıkarım. }\end{array}$ & & & & & \\
\hline 9 & Bir dersten başarısız olduğumda bunu düzeltmek için çabalarım. & & & & & \\
\hline 10 & $\begin{array}{l}\text { Sıra arkadaşım beni konuşturmaya çalışsa da dikkatimi derse } \\
\text { veririm. }\end{array}$ & & & & & \\
\hline 11 & $\begin{array}{l}\text { Arkadaşlarım ders sırasında onları rahatsız edecek şeyler yaptığımı } \\
\text { söyler. }\end{array}$ & & & & & \\
\hline 12 & $\begin{array}{l}\text { Sinavlardan önce birinin bana hatırlatmasına gerek kalmadan sınav } \\
\text { için çalışmaya başlarım. }\end{array}$ & & & & & \\
\hline
\end{tabular}

